\title{
AUSTRALASIAN JOURNAL OF
} PARAMEDICINE

PARAMEDICS

AUSTRALASIA

\section{Research}

\section{Traffic accident first aid training for police officers: a safe community model in Malang, Indonesia}

Bintari Ratih Kusumaningrum SKep, Ns, MKep, is Lecturer'; Ikhda Ulya SKep, Ns, MKep is Lecturer ${ }^{1}$; Dewi Kartikawati Ningsih SKep, Ns, MPH is Lecturer and PhD Candidate ${ }^{1}$

Affiliations:

${ }^{1}$ Nursing School, Faculty of Medicine, Universitas Brawijaya, Malang, Indonesia

https://doi.org/10.33151/ajp.16.728

\section{Abstract}

\section{Introduction}

Police officers hold an important role as first responders as they usually reach the location of a traffic accident before paramedics. They also provide a level of safety for traffic accident victims while still at the accident scene. This study examined the effects of first aid training for police officers and their ability to assist people involved in traffic accidents as a part of a safe community model.

\section{Methods}

The study employed a pre-experimental design with a one-group pre-test/post-test approach. The recruited sample was made up of 19 police officers from Malang Resort Police Station, chosen by using the cluster technique applied to areas with high accident levels. The instruments used were questionnaires, assessing the officers' knowledge of first aid, as well as observation sheets measuring their skills in providing first aid.

\section{Results}

The results were analysed using a Wilcoxon test, which showed a significant effect $(p<0.0001)$ of first aid training for a traffic accident on the knowledge and skills of police officers as a part of a safe community model.

\section{Conclusion}

First aid training is a strategy that should be implemented in order to support a safe community model. It is suggested that this training be conducted regularly by means of collaboration between police stations and medical services in order to improve prehospital services, which currently are limited in Indonesia.

Keywords:

police officers, first aid, safe community

Corresponding Author: Bintari Ratih Kusumaningrum, bintariratih@ub.ac.id 


\section{Introduction}

Road traffic accidents are a leading cause of death and disabaility in people aged 5 to 29 years, especially in developing countries. The World Health Organization noted that in 2018, annual traffic deaths had reached 1.3 million worldwide (1). Traffic accident victims include 20 to 50 million people who suffer mild to severe injuries and 3500 deaths per day worldwide (2). In Indonesia, the number of traffic accidents in 2010 was 104,824, most of which occurred in areas of East Java, with 23,259 deaths (3).

When a traffic accident occurs, first aid given to victims immediately is a crucial measure to minimise fatal outcomes and severe injury (4). Therefore, to minimise disability and improve the safety of victims, correctly performed first aid is of the utmost necessity. First aid can be performed by bystanders at an accident scene (5). Police officers have an important role as first responders. They also provide a level of safety for traffic accident victims at the location of the accident. This is because there is no specific pre-hospital service in Malang. A solution is being sought for this shortcoming.

The problem of limited resources and lack of a pre-hospital service system can be overcome by improving local capacity. Local capacity building is a strategy that empowers citizens, or specifically-intended citizens, to act as first responders at accident locations. This empowerment can improve a citizen's capacity in properly providing first aid for traffic accident victims. The improvements can be made by conducting a first aid training program for citizens and specifically-intended citizens, such as police officers. Local capacity building can be strengthened by building a safe community which involves multiple sectors, namely 118 (emergency calls), police officers and locals (6).

Geduld and Wallis developed a pre-hospital care system by empowering taxi drivers as first responders in Madagascar in 2011. Their study showed an improvement of the knowledge and skills in providing pre-hospital care (7). Therefore, in line with the results of that study, this study aimed to find out the effects of first aid training for police officers and their ability to assist people involved in traffic accidents. The empowerment of first responders was integrated into a safe community care model in pre-hospital care.

\section{Methods}

\section{Study design}

This study employed a pre-experimental model with one group pre-test/post-test approach. There was no control group present in this study.

\section{Participants}

The sampling was taken by cluster, based on areas with high frequency of accidents in Malang. The sample was 21 police officers, with inclusive criteria of: being a member of Malang Resort Police stationed in traffic posts; not having been involved in any research activity 2 years before this study; and being 20 to 55 years of age. The final number of participants was 19. Two participants were excluded because of their extra duties within the station.

\section{Procedure}

Participants were trained in first aid for traffic accident victims for 10 hours. Training consisted of: checking consciousness level; respiratory tract obstruction, and adequacy of respiration and circulation as well as performing care for obstruction in respiratory tract-respiration-circulation; stopping bleeding; splinting; bandaging; and methods to carry and move victims. The study was conducted in the Faculty of Medical Science at Brawijaya University, Indonesia, in July 2017.

\section{Data collection}

We used questionnaire observation sheets and interviews to obtain the data. The questionnaire contained personal details of the respondents, description of previous training in first aid, and knowledge of first aid for traffic accident victims. The observation sheets contained a five-item checklist of necessary first aid skills for traffic accident victims. We conducted interviews to understand and record what the participants felt about the experience of training and what they expected from the study.

The questionnaire employed in this study was a modification of the ones proposed by Jayaraman (8) and Olumide (9). This questionnaire consisted of 16 questions about checking consciousness level, respiratory tract obstruction, adequacy of respiration and circulation, correctly performed care for obstruction in respiratory tract-respiration-circulation, and methods to carry and move victims. Instrument validity test was conducted using the security officers of Brawijaya University.

Data were taken twice: before and after the intervention. Before the intervention, the respondents were asked to complete the questionnaire and were observed for their basic skills. Following that, the respondents were provided with training conducted over two sessions, namely theoretical and practical sessions. At the end of 10 hours of training, the respondents were asked to complete the second questionnaire and were observed for the second time to measure their skills.

\section{Data analysis}

Data analysis was descriptive and inferential statistics were conducted by SPSS 17.0 with a significance level of 0.05 . Descriptive analysis showed demography data of participants including age, education level, job description and pre-hospital care handled by police. To measure the knowledge and skill pre- and post-intervention, we used the Wilcoxon signed-rank test. 


\section{Ethics approval}

Ethics approval was obtained from the Ethics Committee of Polytechnic of Health the Ministry of Health Malang Indonesia. Informed consent was obtained from the participants.

\section{Results}

\section{Respondent characteristics and descriptions of first aid provided}

The respondents totalled 19 police officers with an age range of 22 to 53 years (mean age value 35.7 years) and a working duration range of 1 to 22 years (mean value 6.7 years). The majority of the respondents completed their high school education (Table 1).

Table 1. The average age of respondents' and work duration in the traffic unit

\begin{tabular}{|c|c|c|c|c|c|}
\hline & N & Minimum & Maximum & Mean & $\begin{array}{c}\text { Deviation } \\
\text { Std. }\end{array}$ \\
\hline $\begin{array}{c}\text { Age } \\
\text { (years) }\end{array}$ & 19 & 22.00 & 53.00 & 35.5789 & 8.56554 \\
\hline $\begin{array}{c}\text { Work } \\
\text { duration } \\
\text { (years) }\end{array}$ & 19 & 1.00 & 22.00 & 6.7895 & 6.23234 \\
\hline
\end{tabular}

Source: Primary Data, 2017

Table 2 shows the five first aid skills for traffic accidents provided by police officers. The most common traffic accidents self-reported by the police officers before the training was vehicles $(84.1 \%)$, with abrasion $(47.4 \%)$ as the most common injury. The most common first aid provided by the police officers when handling traffic accidents was taking the victims to the hospital (52.6\%). However, among the 19 respondents, seven $(38 \%)$ did not possess any first aid skills to assist with this. The equipment mostly available at hand was bandages (15.8\%).

Table 3 and Table 4 show a significant rise in the knowledge and skills before and after the intervention. Wilcoxon's signed-rank test was performed to find the difference in the respondents' knowledge and skills on first aid before and after the intervention and shows a $p=0.000$, which means that there have been significant effects of first aid training for traffic accidents as a part of the safe community model.

The results of observation and interviews with the respondents have shown that the police officers are pleased with the training because they benefit greatly from it in performing their daily duties. With the officers having previously had no training in first aid, these officers hope that training could be held regularly to build their confidence in assisting traffic accident victims.
Table 2. First aid traffic accident victims provided by police officers

\begin{tabular}{|l|l|}
\hline Variables & Total (\%) \\
\hline \multicolumn{1}{|c|}{ Types of accidents mostly cared for } & \\
\hline Vehicle crash accidents & $16(84.1)$ \\
\hline Mild accidents & $1(5.3)$ \\
\hline Pedestrian traffic accidents & $1(5.3)$ \\
\hline People falling from motorcycles & $1(5.3)$ \\
\hline \multicolumn{1}{|c|}{ Most common injuries } & \\
\hline Abrasion & $9(47.4)$ \\
\hline Head trauma & $3(15.8)$ \\
\hline Fractures & $6(31.5)$ \\
\hline Deaths & $1(5.3)$ \\
\hline \multicolumn{1}{|c|}{ First aid given } & \\
\hline Taken to the hospital & $10(52.6)$ \\
\hline Given drink & $2(10.5)$ \\
\hline Checking for ABC and consciousness & $3(15.8)$ \\
\hline Simple care & $3(15.8)$ \\
\hline No assistance & $1(5.3)$ \\
\hline \multicolumn{1}{|c|}{ Equipment used } & \\
\hline Betadine & $2(10.5)$ \\
\hline Splint & $2(10.5)$ \\
\hline Cloth & $2(10.5)$ \\
\hline Car & $2(10.5)$ \\
\hline Wood planks & $4(21.1)$ \\
\hline Bandage & $3(15.8)$ \\
\hline Anything & $1(5.3)$ \\
\hline Stretcher & $2(10.5)$ \\
\hline Nothing & $1(5.3)$ \\
\hline First aid skills & $2(10.5)$ \\
\hline Victim evacuation & $1(5.3)$ \\
\hline Stopping bleeding & $7(36.8)$ \\
\hline Giving drink & $2(10.5)$ \\
\hline Applying Betadine & $2(10.5)$ \\
\hline First aid kit & $1(5.3)$ \\
\hline Installing splint & $3(15.8)$ \\
\hline Checking pulse & $1(5.3)$ \\
\hline Nothing & \\
\hline Source: Primary Data, & \\
\hline
\end{tabular}

Source: Primary Data, 2017 
Table 3. Descriptive analysis of the average score of police officers' knowledge about first aid

\begin{tabular}{|c|c|c|c|c|c|}
\hline Variables & Mean & $\begin{array}{c}\text { Minimum } \\
\text { score }\end{array}$ & $\begin{array}{c}\text { Maximum } \\
\text { score }\end{array}$ & $\begin{array}{c}\text { Deviation } \\
\text { Std. }\end{array}$ & $\begin{array}{c}\text { Wilcoxon } \\
\text { signed- } \\
\text { rank test } \\
\text { (p-value) }\end{array}$ \\
\hline $\begin{array}{c}\text { Pre-test } \\
\text { score }\end{array}$ & 58.3 & 43 & 75 & 9.5 & 0.000 \\
\hline $\begin{array}{c}\text { Post-test } \\
\text { score }\end{array}$ & 80.3 & 68 & 100 & 7.9 & \\
\hline
\end{tabular}

Source: Primary Data, 2017

Table 4. Descriptive analysis of the average score of police officers' first aid skills

\begin{tabular}{|c|c|c|c|c|c|}
\hline Variables & Mean & $\begin{array}{c}\text { Minimum } \\
\text { score }\end{array}$ & $\begin{array}{c}\text { Maximum } \\
\text { score }\end{array}$ & $\begin{array}{c}\text { Deviation } \\
\text { Std. }\end{array}$ & $\begin{array}{c}\text { Wilcoxon } \\
\text { signed } \\
\text { rank test } \\
(p-v a l u e)\end{array}$ \\
\hline $\begin{array}{c}\text { Pre-test } \\
\text { Score }\end{array}$ & 33.6 & 25 & 60 & 8.9 & 0.000 \\
\hline $\begin{array}{c}\text { Post-test } \\
\text { Score }\end{array}$ & 67.9 & 50 & 75 & 6.7 & \\
\hline
\end{tabular}

Source: Primary Data, 2017

\section{Discussion}

An organised pre-hospital service system is currently unavailable in Malang. Empowerment of citizens and specifically-intended citizens, including the police force, has become an important factor in the development of pre-hospital services in handling traffic accident victims as an embodiment of a safe community program (10). In many traffic accident cases, the actions of police officers supported the medical practitioners. Therefore, improving training in basic first aid is needed as the police force is also responsible for giving first aid to victims of traffic accidents.

The results of this study show that traffic accidents involving vehicles are mostly reported by the police. The volume of motorised vehicles has increased over time. In 2014, the number of motorised vehicles reached 92,976,240 in Indonesia (11). Along with this increasing number, the number of traffic accidents has subsequently risen (12).

Abrasions were the most commonly treated injury reported by participants in this study, and according to the data collected by the Malang Resort Police Station (year), most mild injuries reported were abrasions. A contributing factor to the minor nature of the accidents may be that most roads in the Malang area are inner-city roads. Therefore, larger sized vehicles are required to maintain low speeds when entering the inner-city area.

When there was a traffic accident, the police officers were required to take the victims to the hospital immediately. There was not much they could do upon arriving at the location because, based on the data, their skills in giving first aid were minimal. This finding is similar to that of previous research about the experience of police officers in giving first aid to a traffic accident victim in the Pasuruan Traffic Post area. Most police officers have an inadequate understanding of providing first aid for traffic accident victims (13).

In Malang, district hospitals provide pre-hospital services on request. However, according to an interview with a nurse in the emergency department of the Saiful Anwar General Hospital Malang, in a preliminary study in 2016, the statistics from the hospital's 119 calls show that most calls have come from medical cases, not trauma or accident victims. Most traffic accident victims were sent to the hospital by police officers using any available mode of transportation and with minimum care. This finding is consistent with the research finding that police officers are forced to perform minimum first aid with barely adequate equipment and transportation modes. This situation is supported by previous research findings that shows traffic accident victims have mostly been taken by police officers to the nearest health centre for treatment (14).

The equipment available to police officers when performing first aid for traffic accident victims is also minimal. This is shown by the data in which the equipment used mostly for assisting the victims includes wooden planks and bandages that are barely enough to dress bleeding wounds. According to previous qualitative research, needing to maintain immobilisation of patients with a fracture, police officers in Purwodadi Traffic Post often performed first aid by using splints, frequently modifying the splints by using any alternative material because of the unavailability of proper equipment when arriving at the location of the accident. The most common material used to substitute splints is wooden planks (13).

\section{Effects of first aid training as a part of the safe community model}

The results of the data analysis suggest there have been significant improvements in first aid training for traffic accident victims on the knowledge and skills of the police officers in the Malang Traffic Post area. With training, the safe community model can be supported. The safe community model is a way to build a better pre-hospital service to improve the safety level of traffic accident victims (15). The safe community model can be implemented to support medical services provided in hospitals, particularly when emergency medical services (EMS) are still unavailable. The safe community model empowers civilians in handling emergencies outside the hospital. This model was created because currently there is no efficient EMS system in Indonesia (10).

First aid training for police officers can improve their knowledge and skills. Therefore, pre-hospital services performed by these officers may alleviate the number of fatalities associated with 
traffic accidents. The results of observation and interviews with the respondents have shown that police officers are pleased with the training because it assists them in performing their duties. In addition, having had no previous training in first aid, these officers anticipate that the training can be held regularly to build their confidence in assisting traffic accident victims.

These findings are supported by previous research on the experience of police officers as providers of first aid at traffic accidents in the Pasuruan Traffic Post area (13). It further suggests that all police officers be trained in providing first aid for traffic accident victims (13). Simple methods in providing first aid for traffic accident victims could include how to immediately examine victims, how to handle fractures and how to handle a cardiac arrest, as well as equipping all police officers with necessary skills when handling traffic accident victims.

The findings of this study contribute input for policymakers to build a system integrating the police force and civilians, and hospitals and other medical facilities. Furthermore, the government is urged to provide a policy to create an allencompassing EMS system. The integration of such services can, in turn, improve the response time so that all victims of traffic accidents can be handled immediately, correctly and cost-effectively.

\section{Limitations of this study}

The results showed that first aid as part of a safe community model can improve the ability of police officer as first responders in providing first aid to the victims, but it is not known how long the police retain this ability after initial training. Therefore, further research needs to be carried out that performs serial measurement of ability to determine the recommendations for how long training should be carried out, and the need for retraining.

\section{Conclusion}

The unavailability of an organised EMS system in Indonesia has necessitated the need for medical practitioners to give first aid education to civilians and first responders. First aid training has brought about a significant impact on the knowledge and skills of the police force in giving first aid. Therefore, first aid training can help support the safe community model within the limited pre-hospital care available in Indonesia. Further studies may employ time-series designs to explore the retention of first aid knowledge among police officers.

\section{Acknowledgement}

The authors would like to thank the Universitas Brawijaya for funding this study, Police Resort Malang Indonesia, and Traffic
Police division of Malang.

\section{Conflict of interest}

The authors report no competing interests. Each author of this paper have completed the ICMJE conflict of interest statement.

\section{References}

1. World Health Organization, 2018. Global status report on road safety 2018. Available at: www.who.int/violence injury_prevention/road_safety_status/2018/en [Accessed 16 July 2019].

2. Agnihotri AK. Road traffic injuries - a global public health concern. Emerg Med 2012;2:3.

3. Kementrian kesehatan, 2012. Profil data kesehatan Indonesia tahun 2011. Available at: www.depkes.go.id [Accessed 22 February 2013].

4. Kureckova V, Gabrhel V, Zamecnik P, et al. First aid as an important traffic safety factor - evaluation of the experiencebased training. European Transport Research Review 2017;9(1). Available at: https://doi.org/10.1007/s12544-0160218-4

5. Khorasani-Zavareh D, Khankeh HR, Mohammadi R, et al. Post-crash management of road traffic injury victims in Iran. Stakeholders' views on current barriers and potential facilitators. BMC Emerg Med 2009;9:1-8.

6. Pusponegoro AD. 2011. The Silent Disaster: Bencana dan Korban Massal. Sagung Seto: Jakarta.

7. Geduld $H$, Wallis L. Taxi driver training in Madagascar: the first step in developing a functioning prehospital emergency care system. Emerg Med J 2011;28:794-6. doi:10.1136/ emj.2010.101683

8. Jayaraman S, Mabweijano JR, Lipnick MS, et al. Current patterns of prehospital trauma care in Kampala, Uganda and the feasibility of a lay-first-responder training program. World J Surg 2009;33:2512-21.

9. Olumide AO, Asuzu MC, Kale OO. Effect of first aid education on first aid knowledge and skills of commercial drivers in south west Nigeria. Prehosp Dis Med 2015;30:579-85.

10.Suryanto, Boyle M, Plummer V. The prehospital and healthcare system in Malang, Indonesia. Australasian Journal of Paramedicine 2017;14(2).

11. Badan Pusat Statistic. 2017. Perkembangan Jumlah Kendaraan Bermotor Menurut Jenis, 1949-2017. Available at: www.bps.go.id/linkTableDinamis/view/id/1133.

12. Marsaid H, Ahsan M. Faktor Yang Berhubungan Dengan Kejadian Kecelakaan Lalu Lintas Pada Pengendara Sepeda Motor Di Wilayah Polres Kabupaten Malang. Jurnal IImu Keperawatan 2013;1:98-112.

13.Ulya I. Studi Fenomenologi: Pengalaman Petugas Kepolisian Dalam Memberikan Tindakan Pertolongan Pertama Korban Kecelakaan Lalu Lintas. Majalah Kesehatan 2017;4:4. 


\section{References (continued)}

14. Kusumaningrum BR, Winarni I, Setyoadi K, Ratnawati R. Pengalaman Perawat Unit Gawat Darurat (UGD)
Puskesmas dalam Merawat Korban Kecelakaan Lalu Lintas. Jurnal IImu Keperawatan 2013;1:83-90.

15. World Health Organization, 2005. Prehospital trauma care systems. Jenewa. Available at: https://apps.who.int/iris/ bitstream/handle/10665/43167/924159294X.pdf 